Matta, E., Selge, F., Gunkel, G., Rossiter, K., Jourieh, A., \& Hinkelmann, R.

\title{
Simulations of nutrient emissions from a net cage aquaculture system in a Brazilian bay
}

Journal article | Accepted manuscript (Postprint)

This version is available at https://doi.org/10.14279/depositonce-7288

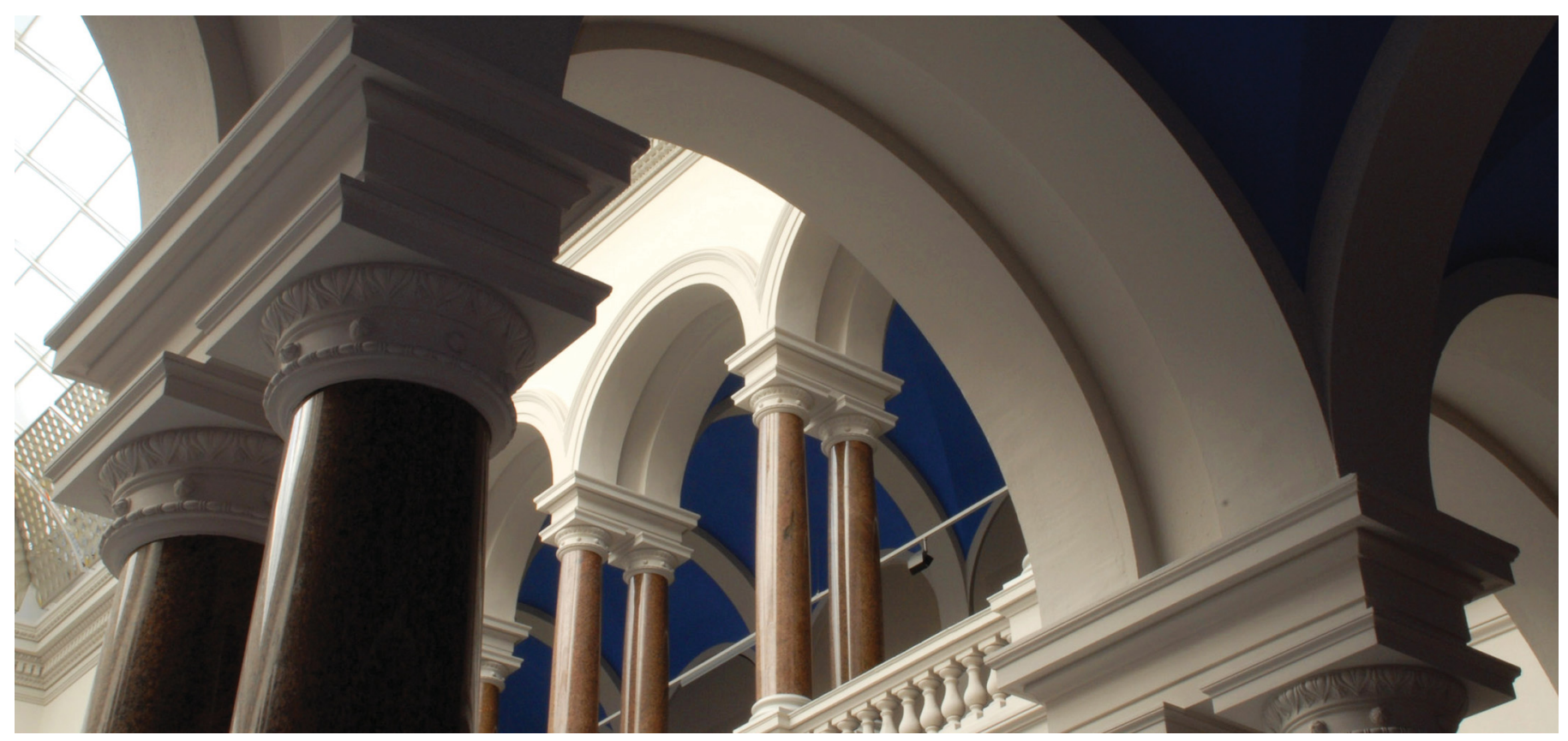

(C)IWA Publishing 2016. The definitive peer-reviewed and edited version of this article is published in Water Science and Technology 73, 10, pp. 2430-2435, 2016, 10.2166/wst.2016.092 and is available at www.iwapublishing.com.

Matta, E., Selge, F., Gunkel, G., Rossiter, K., Jourieh, A., \& Hinkelmann, R. (2016). Simulations of nutrient emissions from a net cage aquaculture system in a Brazilian bay. Water Science and Technology, 73(10), 2430-2435. https://doi.org/10.2166/wst.2016.092 


\title{
Simulations of nutrient emissions from a net cage aquaculture system in a Brazilian bay
}

\author{
E. Matta*, F. Selge**, G. Gunkel**, K. Rossiter***, A. Jourieh* \& Reinhard Hinkelmann* \\ * Technische Universität Berlin, Chair of Water Resources Management and Modeling of Hydrosystems, Gustav-Meyer-Allee \\ 25, 13355 Berlin, Germany: elena.matta@wahyd.tu-berlin.de, reinhard.hinkelmann@wahyd.tu-berlin.de, \\ ayman.jourieh@wahyd.tu-berlin.de \\ ** Technische Universität Berlin, Chair of Water Quality Control, Straße des 17. Juni 135, 10623 Berlin, Germany: \\ florian.selge@tu-berlin.de,guenter.gunkel@tu-berlin.de \\ *** Universidade Federal do Pernambuco, Av. Professor Morais Rego, Recife - PE, 50670-901, Brazil: \\ karina_rossiter@yahoo.com.br
}

\begin{abstract}
Hydrodynamics and transport simulations were conducted with the modeling software TELEMAC-2D on Icó-Mandantes bay, a branch of the Itaparica reservoir. The bay has a maximal operational water level amplitude of 5 $\mathrm{m}$ and is suffering for eutrophication and algae bloom. Therefore, we investigated low and high water level scenarios with two different high resolution meshes, with the purpose to deeper understand their impact on transport of substances and to improve the watershed management. In particular, nutrient emissions from a hypothetical net cage aquaculture system located in the bay were investigated on half-year cycles. We observed a relevant impact on water quality for a tilapia production of $130 \mathrm{t} \mathrm{y}^{-1}$, i.e. after 6 months simulation we obtained around $8 \mu \mathrm{gP} \mathrm{L}^{-1}$ and $6 \mu \mathrm{gP} \mathrm{L}^{-1}$ at the source of emissions, for low and high water scenario, respectively.
\end{abstract}

Keywords: Itaparica reservoir; water level change; transport; São Francisco River

\section{Introduction}

Many reservoirs in Brazil were built within the last 50 years, primarily for water storage and energy production, without a conscious consideration of the environment. As a general consequence, large-dam construction in the 1960s and 1970s strongly interfered with river functioning and the hydrological cycles, producing many changes in these cycles and in the biodiversity related to the rivers (Tundisi \& Matsumura-Tundisi 2003). Human intervention affects irreversibly water flows natural state, with a huge social and ecological impact. In Itaparica reservoir, located in the semiarid Pernambuco, Northeast Brazil, climate and land-use changes as well as multiple uses of water lead to water quality problems (Gunkel \& Sobral 2013). Surface water conservation, both for water quality and quantity aspects, is strategic for the sustainable development of the region (Araújo et al. 2003). Therefore, it is necessary to face the social, political and ecological issues with the help of multi- and trans-disciplinary studies, in order to find enhanced management options for the future. This is one of the purposes of the INNOVATE project (Interplay among multiple uses of water reservoirs via innovative coupling of substance cycles in aquatic and terrestrial ecosystems), a joint research in collaboration between Germany and Brazil, which this work belongs to.

Object of the study is Icó-Mandantes bay, a shallow eutrophic bay, located approximately in the middle of Itaparica reservoir. A map of the study site can be found in Matta et al. (2014). Previous research in the area showed that exchange with the reservoir main stream hardly occurs, as long as wind is neglected (Özgen et al. 2013; Broecker et al. 2014; Matta et al. 2014). Water multiple uses (e.g. irrigation agriculture), water level fluctuations and shore's desiccation, caused by high evaporation rates (ca. 2,000 $\mathrm{mm} \mathrm{y}^{-1}$ ), are overstressing the bay, isolating it from the river (Selge et al. 2015). In this work, we simulated hydrodynamics and transport using TELEMAC-2D, in order to quantify the mechanisms and timescales of exchange between Icó-Mandantes bay and the 
reservoir main stream, according to different water elevations. We investigated in particular nitrogen and phosphorus dissolved ions emissions from an aquaculture system hypothetically located in the bay, to quantify the potential impacts on water quality.

\section{Material and Methods}

\section{Modeling tools}

The bathymetry of the model was set up using measured data mapping, conducted by echo sounder profiling during different field campaigns, performed between 2012 and 2014 (Selge et al. 2015). The data were imported and elaborated with the help of Janet (Smile Consult GmbH), an efficient tool to generate and edit grids for numerical simulations. TELEMAC-2D, a module of the TELEMAC-MASCARET system (Laboratoire National d'Hydraulique et Environnement (LNHE), part of the R\&D group of Électricité de France), was used as processor. It is a powerful integrated modeling tool for free-surface flows and it solves the two-dimensional shallow water and transport equations with complex algorithms mainly based on the Finite Element Method, computing the water depth, the two velocity components and the depth averaged concentration at each point of the mesh (Hervouet 2007). After each computation, the results were examined with the help of ParaView, an open-source multi-platform data analysis and visualization application (Ayachit 2015).

\section{Governing equations}

The governing equations are the two-dimensional depth-averaged shallow water and transport equations. The shallow water equations consist of the continuity and the momentum equations in $\mathrm{x}$ - and y-direction (Equation 1, 2, 3):

$\frac{\partial h}{\partial t}+\frac{\partial u h}{\partial x}+\frac{\partial v h}{\partial y}=0$

$\frac{\partial u h}{\partial t}+\frac{\partial u^{2} h}{\partial x}+\frac{\partial u v h}{\partial y}-\frac{\partial}{\partial x}\left(v_{t} \frac{\partial u}{\partial x} h\right)-\frac{\partial}{\partial y}\left(v_{t} \frac{\partial u}{\partial y} h\right)=h\left(\frac{f_{x}}{\rho}-g \frac{\partial\left(h+z_{b}\right)}{\partial x}\right)$

$\frac{\partial v h}{\partial t}+\frac{\partial u v h}{\partial x}+\frac{\partial v^{2} h}{\partial y}-\frac{\partial}{\partial x}\left(v_{t} \frac{\partial v}{\partial x} h\right)-\frac{\partial}{\partial y}\left(v_{t} \frac{\partial v}{\partial y} h\right)=h\left(\frac{f_{y}}{\rho}-g \frac{\partial\left(h+z_{b}\right)}{\partial y}\right)$

where $\mathrm{u}$ and $\mathrm{v}$ are the $\mathrm{x}$ - and $\mathrm{y}$-component of the velocity vector, respectively, $v_{t}$ is the turbulent viscosity (assumed constant and equal to $v_{t}=10^{-4} \mathrm{~m}^{2} \mathrm{~s}^{-1}$ ), $f_{x}$ and $f_{y}$ are the shear stresses (at the bottom and at the surface) in $\mathrm{x}$ - and y-direction, respectively, $h$ is the water depth, $g$ is the gravity acceleration, $\rho$ is the fluid density and $z_{b}$ is the bottom elevation.

The bottom and the surface friction (i.e. wind) are respectively determined through the Strickler law and the empirical Flather's approach, where the relevant parameters are the Strickler coefficient for the first, the wind velocity and a wind shear stress coefficient, dependent on wind velocity and direction, for the second. More information about the consideration of wind forcing in the TELEMAC system may be found in (Hervouet 2007). A mean wind of $5.5 \mathrm{~m} \mathrm{~s}^{-1}$ blowing from South-East with an angle of $140^{\circ}$ (Matta et al. 2014) and a Strickler bottom friction coefficient of $30 \mathrm{~m}^{0.33} \mathrm{~s}^{-1}$ (Cirilo 1991) were chosen for each case studied.

The depth-averaged transport equation is shown in Equation 4:

$\frac{\partial c}{\partial t}+u \frac{\partial c}{\partial x}+v \frac{\partial c}{\partial y}-\frac{\partial}{\partial x}\left(v_{t, t} \frac{\partial c}{\partial x}\right)-\frac{\partial}{\partial y}\left(v_{t, t} \frac{\partial c}{\partial y}\right)=0$ 
where $c$ is the concentration and $v_{t, t}$ is the turbulent diffusivity (assumption: $v_{t, t}=10^{-4} \mathrm{~m}^{2} \mathrm{~s}^{-1}$ ).

We considered only conservative transport in our study, simulating phosphorus and nitrogen emissions. This means that biological or chemical reactions and feedback effects of the transport with the flow are not taken into account. The evolution in time of the transported substances depends on advection (most relevant) and diffusion, whose terms are shown in Equation 4.

Further, two-dimensional simulations are carried out, i.e. vertical variations of the velocity or concentration are also not considered.

\section{Preprocessing}

Water level fluctuations are common phenomena in semi-arid areas due to rain seasons, high evaporation rates and hydropower generation. These changes play an important role for water quality by aquatic biodiversity development, nutrient release from desiccated areas and therewith water quantity management becomes a major tool for aquatic ecosystem control in these regions. Therefore, the study cases were investigated according to high and low water levels, in order to compare the respective results. Two unstructured triangular grids with high resolution were set up with the software Janet, one for low water level (LWL) and one for high water level scenarios (HWL) (Tab. 1).

Table 1 Characteristic parameters of the grids

\begin{tabular}{|l|l|l|l|}
\hline \multicolumn{4}{|l}{ High resolution models with unstructured mesh } \\
\hline Water level & $\begin{array}{l}\text { Maximum bottom } \\
\text { elevation (m a.s.1.) }\end{array}$ & $\begin{array}{l}\text { Prescribed water } \\
\text { elevation (m a.s.1.) }\end{array}$ & $\begin{array}{l}\text { Number of } \\
\text { triangular cells (-) }\end{array}$ \\
\hline LWL & 299.5 & 300.0 & 17,000 \\
\hline HWL & 302.8 & 304.0 & 23,000 \\
\hline
\end{tabular}

The computational domain has an area of around $100 \mathrm{~km}^{2}$ : it covers Icó-Mandantes bay and it includes a part of São Francisco River, concerning the inflow and the outflow (Fig. 1). São Francisco river, the longest in Brazil with about 2,914 $\mathrm{km}$ length, crosses the area and it is interrupted in its flow by the Luiz Gonzaga dam, forming the Itaparica reservoir: a large basin of about $828 \mathrm{~km}^{2}$, with a regulated mean flow of $2,060 \mathrm{~m}^{3} \mathrm{~s}^{-1}$ and a mean water elevation of $302.8 \mathrm{~m}$ a.s.1.

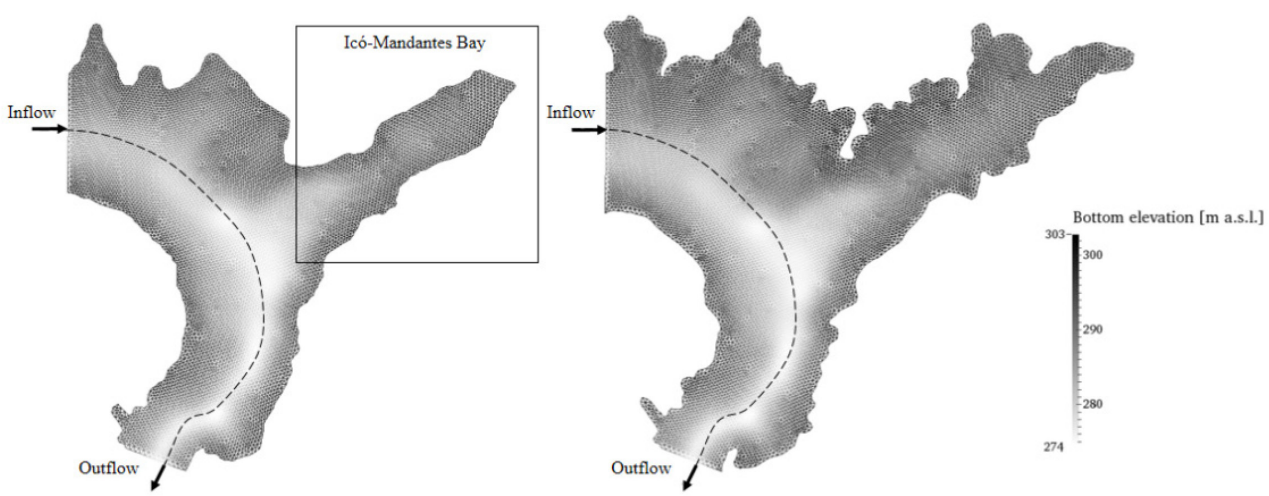

Figure 1 Unstructured high resolution grid for LWL (left) and for HWL (right). The black frame in the LWL grid (left) highlights Icó-Mandantes bay. 


\section{Results and Discussion}

A low water level of $300 \mathrm{~m}$ a.s.l. and a high water level of $304 \mathrm{~m}$ a.s.l. were imposed as constant water elevation for low water level (LWL) and for high water level (HWL) at the outflow boundary, respectively, and a controlled discharge of $2,060 \mathrm{~m}^{3} \mathrm{~s}^{-1}$ as boundary condition at the inflow from Itaparica.

\section{Aquaculture nutrient emissions}

Tilapia production in Itaparica reservoir amounts to 20,000 tons per year. In Brazil, $1 \%$ of the lake surface is allowed to host aquaculture $\left(43,267 \mathrm{t} \mathrm{y}^{-1}\right)$, but there are concerns about the sustainability to this regulation (Gunkel et al. 2013). Net cage fish culture brings a desirable economic development, but can also contaminate water bodies with eutrophication and sediments leading to anoxic conditions (Gunkel et al. 2015). Thus far, Icó-Mandantes bay is not yet interested by any aquaculture system, although it is used e.g. for fishery, irrigation agriculture. Therefore, we thought to model the accumulation of nitrogen and phosphorus dissolved ions emissions from a hypotetical location inside the bay. Their spreading, as well as their retained mass quantities, were observed in time and space.

The choice of the emissions site required a specific care. Since it is necessary to guarantee enough space to allow translocation and dilution of particulate organic material to avoid an extreme sediment increase beneath the cages (Resolução CONAMA 413, 2009; Gunkel et al. 2015), we adopted a point of $5 \mathrm{~m}$ and $9 \mathrm{~m}$ water depth for LWL and HWL respectively, near the southeastern shore of the bay. We assumed a productivity of $130 \mathrm{t} \mathrm{y}^{-1}$, which means that Dissolved Nitrogen (DN) and Dissolved Phosphorus (DP) are equal to around $17.359 \mathrm{~kg} \mathrm{~d}^{-1}$ and $1.302 \mathrm{~kg} \mathrm{~d}^{-1}$, respectively. The emissions were simulated as a daily accumulation of nutrients, implementing a tracer source in TELEMAC-2D. The results were observed after 1 week and 6 months computation. In Table 2 we reported the values of DN and DP in 4 observation points chosen inside the domain (Fig. 2), considering the modeled aquaculture impact for LWL and HWL.

Table $2 \mathrm{DN}$ and DP concentrations $\left[\mu \mathrm{gL}^{-1}\right]$ at 4 observation points chosen inside Icó-Mandantes bay after 1 week and 6 months simulation.

\begin{tabular}{|c|c|c|c|c|c|}
\hline \multicolumn{3}{|c|}{ LWL 1 week } & \multicolumn{3}{c|}{ HWL 1 week } \\
\hline Observation points & DN $\left[\mu \mathrm{gL}^{-1}\right]$ & $\mathrm{DP}\left[\mu \mathrm{gL}^{-1}\right]$ & Observation points & $\mathrm{DN}\left[\mu \mathrm{gL}^{-1}\right]$ & $\mathrm{DP}\left[\mu \mathrm{gL}^{-1}\right]$ \\
\hline 1224 & 0 & 0 & 1224 & 0 & 0 \\
\hline 3972 - source point & 103.120 & 7.735 & $3972-$ source point & 53.164 & 3.988 \\
\hline 6479 & 0 & 0 & 6479 & 0 & 0 \\
\hline 8536 & 0 & 0 & 8536 & 0 & 0 \\
\hline \multicolumn{4}{|c|}{ LWL 6 months } & \multicolumn{3}{c|}{ HWL 6 months } \\
\hline Observation points & DN $\left[\mu \mathrm{gL}^{-1}\right]$ & $\mathrm{DP}\left[\mu \mathrm{gL}^{-1}\right]$ & Observation points & DN $\left[\mu \mathrm{gL}^{-1}\right]$ & $\mathrm{DP}\left[\mu \mathrm{gL}^{-1}\right]$ \\
\hline 1224 & 0.683 & 0.051 & 1224 & 0.403 & 0.030 \\
\hline $3972-$ source point & 110.575 & 8.294 & $3972-$ source point & 74.815 & 5.612 \\
\hline 6479 & 0.012 & 0.001 & 6479 & 0.008 & 0.001 \\
\hline 8536 & 7.497 & 0.562 & 8536 & 4.580 & 0.344 \\
\hline
\end{tabular}




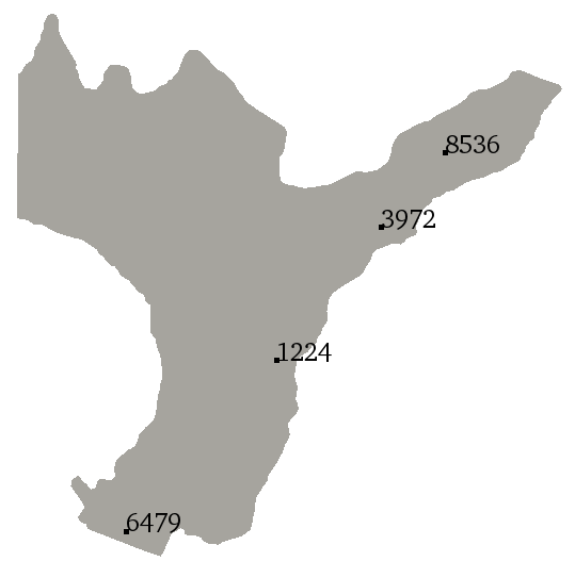

Figure 2 Observation points shown for the LWL grid (3972 is the source of nutrient emissions).

Considering a critical DP concentration of $25 \mu \mathrm{g} \mathrm{L} \mathrm{L}^{-1}$ (Selge et al. 2015), the accumulation of nutrients inside the bay is relevant: after 6 months simulation we obtained around $8 \mu \mathrm{g} \mathrm{L}^{-1}$ and $6 \mu \mathrm{g} \mathrm{L}^{-1}$ at the source of emissions (3972), while about $0.6 \mu \mathrm{g} \mathrm{L}^{-1}$ and $0.3 \mu \mathrm{g} \mathrm{L}^{-1}$ in point 8536, for LWL and HWL respectively. We can notice that the former gained higher concentrations in all observation points compared to the latter. We can state that with low water conditions, nutrients reached higher concentrations inside the bay and they spread faster. For high water conditions, the accumulation lasted longer and substances flew harder out of the bay. The final quantities [kg] that remained inside the bay after 1 week, 1 month and 6 months computation are reported in Table 3 .

Table 3 DN and DP mass quantities [kg] still retained inside Icó-Mandantes bay after 1 week, 1 month and 6 months simulation.

\begin{tabular}{|c|c|c|c|c|c|c|}
\cline { 2 - 7 } \multicolumn{1}{c|}{} & \multicolumn{2}{c|}{1 week } & \multicolumn{2}{c|}{1 month } & \multicolumn{2}{c|}{6 months } \\
\cline { 2 - 7 } \multicolumn{1}{c|}{} & DN $[\mathrm{kg}]$ & DP $[\mathrm{kg}]$ & DN $[\mathrm{kg}]$ & DP $[\mathrm{kg}]$ & DN $[\mathrm{kg}]$ & DP $[\mathrm{kg}]$ \\
\hline Source & 121.513 & 9.114 & 520.770 & 39.060 & 3176.697 & 238.266 \\
\hline LWL & 121.504 & 9.114 & 502.092 & 37.663 & 1385.204 & 103.908 \\
\hline HWL & 121.504 & 9.114 & 519.644 & 38.980 & 2037.925 & 152.870 \\
\hline
\end{tabular}

After 1 week, the entire quantity created by the source term is still inside the domain (s. Fig. 1). After 6 months, $56 \%$ of the initial quantity left the domain for LWL, while for HWL only $36 \%$. Spreading and exchange processes inside Icò-Mandantes bay are slow, given to the extreme slow flow velocities, mainly driven by wind (Matta et al. 2014). The study conducted shows that installation of a net cage aquaculture system inside Icò-Mandantes bay would affect more the water quality of the area under low water conditions on a shorter term, but under high water conditions on a longer term. We can add that concentrations reached higher values for LWL, because water

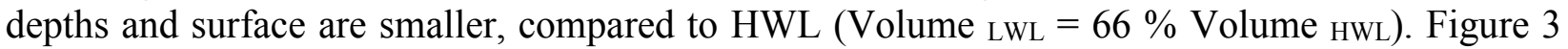
shows the spreading of DN in the computational domain after 6 months simulation. 

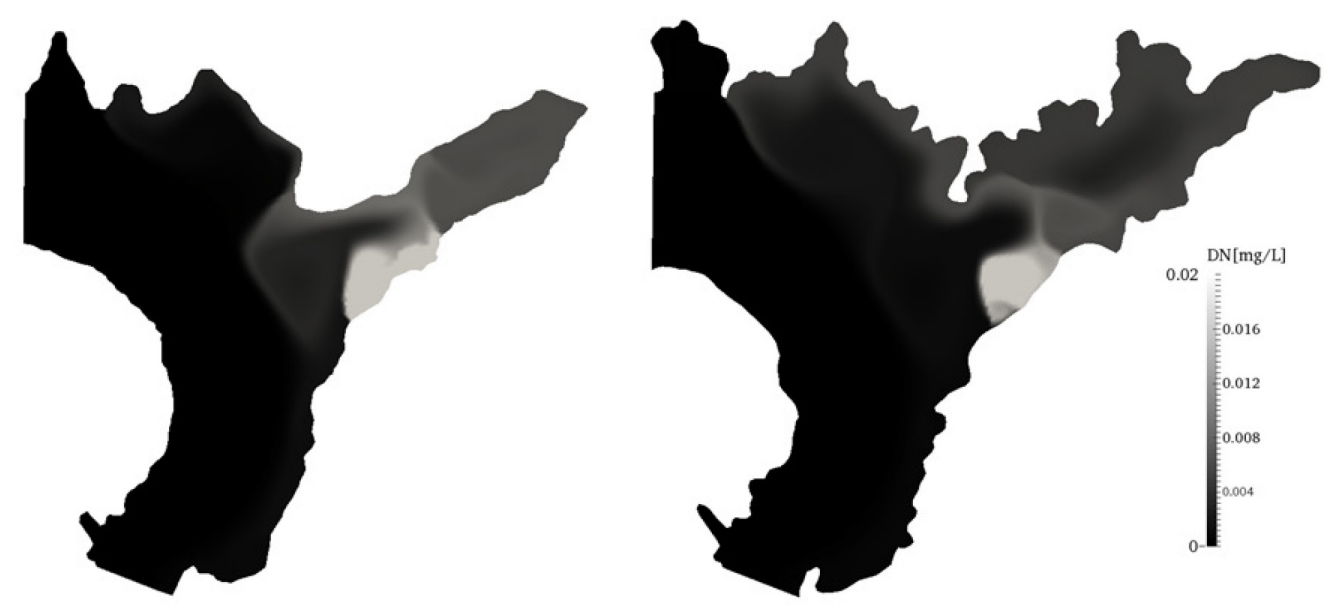

Figure 3 Spreading of DN concentrations $\left[\mathrm{mgL}^{-1}\right]$ inside Icó-Mandantes bay, after a computation of 6 months for LWL (left) and HWL (right).

\section{Conclusions}

Exchange processes between Icó-Mandantes bay and Itaparica reservoir main stream, Northeast Brazil, were investigated for low and high water conditions (abbreviated as LWL and HWL, respectively) using the TELEMAC-2D modeling system. Nutrient emissions were simulated on the long term ( 6 months), in order to understand the potential impacts of a hypothetical net cage aquaculture system inside the bay. The results showed that concentrations of DN and DP reached higher values for LWL and they spread faster inside the bay, while for HWL the mass quantities $[\mathrm{kg}]$ are retained longer in the area (56\% left the domain after 6 months for LWL and only $36 \%$ for HWL).

The results of this study are an additional tool for local companies and decision makers, which can be particularly helpful regarding water quality control, water level regulation of the reservoir, placements of new pumps for irrigation agriculture or of a new net cage aquaculture system.

In further work, also 3D effects (e.g. wind, stratification) will be investigated to observe hydrodynamic changes over the vertical, fulfilling the lacks of 2D modeling.

\section{Acknowledgements}

This work, as part of the INNOVATE project, was financially supported by the German Federal Ministry of Education and Research (BMBF), the Brazilian Conselho Nacional de Desenvolvimento Científico e Tecnológico (CNPq), Ministério da Ciêncía, Tecnologia e Inovação (MCTI) and the Universidade Federal de Pernambuco (UFPE). The support of Dr.-Ing. M. Maghoub is gratefully acknowledged.

\section{References}

Araújo J. C., Fernandes L., Machado J. C. J., Lima Oliveira M. R. and Cunha Sousa T. (2003). Sedimentation of Reservoirs in Semiarid Brazil. In: Global Change and Regional Impacts: Water Availability and Vulnerability of Ecosystems and Society in the Semiarid Northeast of Brazil, Springer, Berlin, pp 205-216.

Ayachit U. (2015). The ParaView Guide: A Parallel Visualization Application. Kitware, New York. 
Broecker T., Özgen I., Matta E., Cabral J., Candeias A. L. and Hinkelmann R. (2014). Simulation of Flow and Transport Processes in a Brazilian Reservoir. Lehfeldt, R. \& Kopmann, R. (eds): International Conference on Hydroscience \& Engineering (ICHE) 2014, Hamburg, Germany, C 2014 Bundesanstalt für Wasserbau, Karlsruhe, Germany.

Cirilo J. A. (1991). Análise dos processos hidrológico - Hydrodinâmicos na bacía do Rio São Francisco. PhD Thesis, Universidade General do Rio do Janeiro, Brazil.

CONAMA (Conselho Nacional do Meio Ambiente) (2009). Resolução no. 413, de 26 de Julho de 2009 (Law resolution no. 413 of the Brazilian Environment Council, published on the 26th of July, 2009). Brazilian Ministry of the Environment. http:/www.mma.gov.br/port/conama/legiabre.cfm?codlegi=608 (accessed 7 March 2016).

Gunkel G. and Sobral M. C. (2013). Re-oligotrophication as a challenge for tropical reservoir management with reference to Itaparica Reservoir, São Francisco, Brazil. Water Sci. Technol., Vol. 67, No. 4, pp. 708-714.

Gunkel G., Steemann J. and Sobral M. C. (2013). Carrying capacity limits in net cage fish production in water reservoirs. In: Sustainable Management of Water and Land in Semiarid Areas. ed. G. Gunkel, J.A. Silva \& M.C. Sobral, Editora Universitária UFPE, Recife, Brazil, pp. 99-117.

Gunkel, G., Matta, E., Selge, F., Nogueira da Silva, G. M. \& Sobral, M. (2015). Carrying capacity limits of net cage aquaculture for Brazilian reservoirs. Revista Brasileira Ciencias Ambientais, subm.

Hervouet J. M. (2007). Hydrodynamics of free surface flows: modelling with the finite element method. Wiley, Chichester, UK.

Matta E., Özgen I., Cabral J., Candeias A.L. and Hinkelmann R. (2014). Simulation of Wind-Induced Flow and Transport in a Brazilian Bay. Lehfeldt, R. \& Kopmann, R. (eds): International Conference on Hydroscience \& Engineering (ICHE) 2014, Hamburg, Germany, (C) 2014 Bundesanstalt für Wasserbau, Karlsruhe, Germany.

Özgen I., Seeman S., Candeias A. L., Koch H., Simons F. and Hinkelmann R. (2013). Simulation of hydraulic interaction between Icó Mandantes bay and São Francisco river, Brazil. In: Sustainable Management of Water and Land in Semiarid Areas. ed. G. Gunkel, J.A. Silva \& M.C. Sobral, Editora Universitária UFPE, Recife, Brazil, pp. 2838 .

Selge F., Matta E., Hinkelmann R. \& Gunkel G. (2015). Nutrient load concept- reservoir vs. bay impacts. Proceedings 17th IWA DIPCON Conference, Berlin, Germany.

Tundisi J. G. and Matsumura-Tundisi T. (2003). Integration of research and management in optimizing multiple uses of reservoirs: the experience in South America and Brazilian case studies. Hydrobiologia 500: 231-242. 